\title{
ANALISIS PENERAPAN GOOD CORPORATE GOVERNANCE DALAM MENINGKATKAN KINERJA KEUANGAN PERUSAHAAN
}

\author{
Budi Gautama Siregar \\ Fakultas Ekonomi dan Bisnis Islam IAIN Padangsidimpuan \\ budigautama@iain-padangsidimpuan.ac.id
}

\begin{abstract}
The implementation of GCG is a concept that regulates the behavior of bank actors, namely company owners, management in carrying out their respective duties and responsibilities to minimize agency problems which in turn can improve the company's financial performance. This study aims to analyze the implementation of good corporate governance in improving financial performance at Islamic Commercial Banks for the 2012-2018 period. The study uses secondary data, namely the financial statements of Islamic Commercial Banks consistently published in the research period, namely 8 Islamic Commercial Banks. Based on the results of data analysis with the help of the eviews application, the results show that the implementation of good corporate governance has no effect on financial performance at Islamic Commercial Banks for the 2012-2018 period.
\end{abstract}

Keywords: GCG, Financial Performance, BUS

\section{PENDAHULUAN}

Kesejahteraan dari pemilik perusahaan merupakan salah satu diantara beberapa tujuan penting perusahaan. Tujuan ini akan dapat dicapai perusahaan jika pihak manajemen mampu meningkatkan kinerja perusahaan (Brigham \& Houston, 2006). Peningkatan kinerja perusahaan akan mengakibatkan peningkatan terhadap nilai perusahaan yang ditandai dengan meningkatnya keinginan investor untuk memiliki saham perusahaan tersebut.

Bank adalah salah satu lembaga yang memiliki andil penting dalam pembangunan bangsa. Tugas utamanya yaitu menghimpun dana dari masyarakat dalam bentuk simapanan kemudian mendistribusikannya kembali kepada masyarakat melalui kredit dan atau yang lainnya guna meningkatkan tingkat kelayakan hidup rakyat Dalam perkembangan sekarang ini bank tersebut dapat digolongkan menjadi dua yaitu bank konvensional dan bank syariah., sehingga masyarakat mempunyai pilihan apakah menggunakan jasa bank syariah atau bank konvensional.

Kinerja keuangan perusahaan menjadi sasaran penting perusahaan agar dapat meningkatkan nilai perusahaan termasuk pada lembaga perbankan. Kinerja keuangan bank merupakan kemampuan dari bank tersebut dalam mengelola dan mamenej sumber daya yang dimilikinya. Pengukuran kinerja keuangan dapat dilakukan dengan menggunakan analisis rasio yaitu alat untuk menganalisis laporan keuangan perusahaan. Analisis rasio bertujuan untuk menggambarkan suatu hubungan antara suatu jumlah tertentu dengan jumlah lainnya, atau antara satu periode dengan periode sebelumnya. Dengan perhitungan analisis rasio akan dapat diketahui tentang kondisi kinerja perusahaan atau bank dari suatu periode ke peride berikutnya.

Rasio profitabilitas merupakan analisis yang digunakan untuk mengukur kemampuan perusahaan dalam memperoleh laba pada periode tertentu. Rasio inilah yang biasanya 
digunakan untuk mengukur kinerja keuangan perusahaan yang terdiri dari Return On Asset (ROA), Return On Equity (ROE), Return On Investment (ROI), profit margin. Dalam penelitian rasio yang digunakan untuk mengukur kinerja keuangan adalah return on assets yaitu kemampuan perusahaan dalam mengelola assetsnya dalam memperoleh earning. Alasannya ini digunakan karena Bank Indonesia juga lebih mementingkan penilaian return on asset karena profitabilitas suatu bank yang diukur dengan asset dengan sumber terbesarnya dari dana pihak ketiga atau masyarakat (Ardhi Abdillah, 2015:4).

Penelitian ini dilakukan pada Bank Umum Syariah periode 2012-2018, dimana ROAnya secara garis besar mengalami penurunan. Di tahun 2017 penurunan yang signifikan terjadi pada PT. Bank Panin Syariah sebesar 10,40 \%, seperti pada tabel berikut:

Tabel 1 Return On Asset Pada PT. Bank Panin Syariah

\begin{tabular}{cccccccc}
\hline \multirow{2}{*}{ Bank Umum Syariah } & \multicolumn{7}{c}{ Return On Assets } \\
\cline { 2 - 8 } & $\mathbf{2 0 1 2}$ & $\mathbf{2 0 1 3}$ & $\mathbf{2 0 1 4}$ & $\mathbf{2 0 1 5}$ & $\mathbf{2 0 1 6}$ & $\mathbf{2 0 1 7}$ & $\mathbf{2 0 1 8}$ \\
\hline PT. Bank Panin Syariah & $3,29 \%$ & $1,03 \%$ & $1,99 \%$ & $1,14 \%$ & $0,37 \%$ & $-10,77 \%$ & $0,22 \%$ \\
\hline Sumber: Data diolah untuk penelitian ini \\
Banyak faktor yang & mempengaruhi & kinerja & perusahaan & diantaranya pengungkapan
\end{tabular}
laporan keuangan, earning manajemen, sistem tata kelola yang baik, dan lain sebagainya. Manajemen perusahaan bertanggung jawab dalam menyediakan informasi dan kondisi perusahaan yang sebenarnya baik kepada pemegang saham maupun pihak yang berhubungan dengannya (Hastuti, 2005).

Namun pada kenyataannya masing-masing pihak yang menjalin kontrak dalam pengelolaan perusahaan yaitu antara pihak manajemen (agent) dengan pemegang saham (prncipal) akan mementingkan kepentingannya masing-masing. Pihak manajemen akan berupaya memenuhi kepentingan terlebih dahulu sehingga menyebabkan terjadinya konflik kepentingan yang menimbulkan keluarnya agency cost. Dalam konteks perusahaan perbankan yang induknya adalah Bank Indonesia, telah mewajibkan seluruh bank termasuk didalamnya bank umum syariah untuk menerapkan Good Corporate Governance (GCG) guna terciptanya sistem perbankan yang efisien, efektif serta sehat (Muh. Arief, 2009:2).

Penelitian yang membahas tentang GCG terhadap kinerja keuangan diantaranya penelitian dari (Putri, 2006; Darmawati, 2005; David, 2011) yang menemukan bahwa kinerja keuangan perusahaan yang indikatornya adalah ROA, ROE dan NIM dipengaruhi oleh GCR secara signifikan. Sementara beberapa hasil penelitian yang juga menemukan hasil bahwa gcg tidak berpengaruh signifikan terhadap kinerja keuangan perusahaan diantaranya penelitian dari (Paradita, 2007). Penelitiannya Agrum menemukan bahwa GCG berpengaruh negatif terhadap kinerja keuangan yang diukur dengan ROA dan ROE.

Pada kondisi saat sekarang ini, penerapan GCG menjadi sebuah keniscayaan guna membangun kepercayaan pihak investor kepada perusahaan. Dengan GCG akan mengakibatkan peningkatan efektivitas operasional perusahaan sehingga dapat kinerja perusahaan tersebut dapat tercapai lebih maksimal. Berdasarkan permasalah dan ketidakkonsistenan hasil penelitian tersebut diatas, maka penelitian ini bertujuan menganalisis penerapan GCR dalam meningkatkan kinerja keuangan perusahaan. Objek penelitian ini 
adalah Bank Umum Syariah periode 2012-2018, kinerja keuangan diukur dengan menggunakan return on assets.

\section{KERANGKA TEORITIS DAN PENGEMBANGAN HIPOTESIS Agency Theory}

Agency teori merupakan sebuah kontrak atau perjanjian antara pemilik perusahaan dengan pihak manajemen tentang pengelolaan perusahaan, dimana pemilik perusahaan memberikan kepercayaan kepada pihak manajemen untuk menjalankan perusahaannya (Scott, 2003). Dalam perjalanannya, masing-masing pihak akan berusaha untuk berupaya untuk mementingkan kepentingan masing-masing sehingga bertentangan dengan kontrak awal yang menimbulkan konflik diantara masing-masing pihak.

Teori keagenan berupaya untuk melakukan penyelesaian konflik diantara pihak agar masing-masing pihak berkomitmen untuk menjalankan perjanjian tersebut. Masing-masing pihak tentu akan berusaha untuk meningkatnya kinerja agar tujuan perusahaan dapat tercapai dan pada akhirnya dapat menaikkan nilai perusahaan dimata investor.

Darmawati, dkk, (2005) terdapat tiga asumsi yang menjadi dasar teori keagenan diantaranya asumsi tentang sifat manusia yang menekankan pada sifat yang lebih mendahulukan kepentingan diri sendiri, asumsi keorganisasian dan asumsi informasi. Asumsi tentang sifat manusia dimana pada umumnya manusia tidak menyukai resiko dan berusaha untuk menghindarinya. Asumsi keorganisasian lebih menekankan pada adanya konflik diantara masing-masing anggota. Asumsi infomasi dimana informasi perusahaan dianggap sebagai sesuatu yang dapat diperjual belikan.

Konflik keagenan yang terjadi antara pemegang saham dengan pihak manajemen dapat diminimalisasi dengan menerapkan corporate governance secara efektif dan efisien. Corporate governance juga akan dapat mengefesiensikan aktivitas operasional perusahaan secara ekonomis dan juga dapat dijadikan sebagai mekanisme dan monitoring kinerja dalam perusahaan (Oktapiyani, 2009)

\section{Good Corporate Governance (GCG)}

GCG merupakan sebuah cara yang dilakukan untuk memastikan bahwa pihak manajemen telah menjalankan perusahaan dengan tepat dan strategis sehingga dapat menjadikan perusahaan dengan baik. Dengan penerapan GCG maka akan terjalin hubungan diantara para pemangku kepentingan pada perusahaan dalam menentukan arah dan tujuan perusahaan tersebut.

Pengendalian terhadap perusahaan sangat diperlukan guna memastikan bahwa pihak manajemen telah menggunakan sumber daya perusahaan sesuai dengan yang seharusnya. Penerapan GCG dalam hal ini akan dapat dijadikan sebagai control (pengendalian) dalam pengelolaan seluruh sumber daya perusahaan sehingga tidak terjadi penyalahgunaan yang dapat menguntungkan pihak manajemen (Nur'ainy, 2013).

Penerapan GCG pada bank umum syariah merujuk pada Surat Edaran Bank Indonesia yang meliputi 11 point diantaranya (1) pelaksanaan tugas dan tanggung jawab dewan komisaris, (2) pelaksanaan tugas dan tanggungjawab dewan direksi, (3) kelengkapan dan pelaksanaan tugas komite, (4) pelaksanaan dan tanggungjawab DPS, (5) pelaksanaan prinsip 
syariah dalam kegiatan penghimpunan dana dan penyaluran dana serta pelayanan jasa, (6) penanganan benturan kepentingan, (7) penerapan fungsi audit internal, (8) penerapan fungsi kepatuhan, (9) penerapan fungsi audit eksternal, (10) transparansi kondisi keuangan dan non keuangan, laporan pelaksanaan GCG dan pelaporan internal, (11) batas maksimum penyaluran dana (Bank Indonesia, 2010).

\section{Kinerja Keuangan Perusahaan}

Kinerja merupakan usaha yang dicapai dalam menjalankan aktivitas yang telah direncanakan sebelumnya. Apabila aktivitas tersebut dapat dilaksanakan sesuai dengan yang direncanakan atau bahkan melebihi, maka dapat dikatakan bahwa kinerjanya baik demikian juga sebaliknya. Demikian juga halnya dalam perusahaan, dimana pihak manajemen harus mampu menjalankan perusahaan sesuai dengan tujuan yang telah ditetapkan dengan menggunakan seluruh sumber daya secara efektif dan efisien.

Fahmi, (2011:24) Kinerja keuangan bank adalah merupakan salah satu capaian dari kinerja perusahaan secara keseluruhan. Kinerja keuangan bank akan dapat menggambarkan usaha yang telah dilaksanakan oleh manajeman bank dalam menjalankan operasional secara keseluruhan. Jumingan, (2011:239) Analisis terhadap kinerja keuangan perusahaan dilakukan guna memastikan apakah perusahaan telah menjalankan perusahaan sesuai dengan aturanaturan yang telah digariskan atau tidak.

Kinerja keuangan perusahaan akan dijadikan oleh investor, kreditor dan pihak lainnya sebagai dasar untuk menilai kondisi perusahaan secara keseluruhan. Pada dasarnya investor mau menanamkan modalnya dalam sebuah perusahaan karena ingin mengharapkan profit, tentu dalam hal ini pihak investor akan sangat berhati-hati dalam mengambil keputusan investasi. Salah satu cara yang dilakukan adalah dengan melakukan analisis kinerja keuangan perusahaan dengan menggunakan rasio keuangan (Prasinta, 2012).

Pengukuran kinerja keuangan pada umumnya dapat dilakukan dengan menggunakan analisis rasio keuangan diantaranya rasio likuiditas, rasio solvabilitas, rasio pertumbuhan perusahaan, rasio profitabilitas, dll. Pengukuran kinerja dalam penelitian adalah dengan menggunakan rasio profitabilitas yaitu Return on Assets (ROA), karena dalam perusahaan perbankan Bank Indonesia lebih mengutamakan nilai profitabilitas yang diukur dengan assetnya yang berasal dari dana simpanan masyarakat (Ardhi Abdillah, 2015:4).

ROA merupakan gambaran tentang usaha yang dilakukan oleh pihak manajemen perusahaan dalam menggunakan asset secara efektif dan efisien pada kegiatan operasionalnya guna memaksimalkan laba. Perusahaan yang baik seharusnya mampu mengoptimalkan asset secara keseluruhan dan mengurangi adanya asset yang menganggur (iddle assets) (OECD, 2004). Kinerja keuangan perusahaan perbankan dapat dilihat dari ROA-nya, semakin besar tingkat ROA yang dihasilkan bank tersebut maka itu menandakan bahwa semakin besar tingkat laba yang diperoleh perusahaan yang juga mengindikasikan bahwa bank telah mampu menggunanakan assetnya secara efektif dan efisien dalam aktivitas operasionalnya. Rasio Return On Asset dirumuskan sebagai berikut:

$$
\mathrm{ROA}=\frac{\text { laba setelah pajak }}{\text { total aset }} \times 100 \%
$$




\section{Good Corporate Governance (GCG) dan Kinerja Keuangan}

GCG pada dasarnya adalah konsep yang mengatur prilaku dari para pelaku bank yaitu pemilik perusahaan, pihak manajemen dalam menjalankan tugas dan tanggungjawab masingmasing sehingga dapat meminimalisasi masalah keagenan. Pada umumnya jika perusahaan mampu menerapkan GCG dalam hal ini adalah Bank Umum Syariah sesuai dengan kebijakan yang telah dikeluarkan oleh Bank Indonesia, maka akan dapat meningkatkan kinerja keuangan bank tersebut. Disamping itu, investor juga akan lebih mempercayai perusahaan yang menerapkan GCG dengan baik sehingga akan tertarik untuk berinvestasi (Prasojo, 2015).

Core dari penerapan GCG ini adalah dapat menjaga kontiniutas bank tersebut baik dari perolehan laba maupun tingkat pertumbuhannya sendiri. GCG ini merupakan sebagai tolak ukur bagi pihak manajemen dalam menjalankan perusahaan sehingga tetap berada pada jalurnya dalam meningkatkan kinerja secara optimal. Dengan penerapan GCG secara efektif akan mengakibatkan proses pengambilan keputusan yang diambil oleh pihak manajemen akan senantiasa memberikan keutnungan bagi semua pihak yang terkait. Kaihatu (2006) corporate governance akan dapat meningkatkan kinerja yang dilakukan perusahaan melalui supervisi kinerja dan senantiasa menerapkan prinsip akuntabilitas terhadap para pihak yang berkepentingan beradasarkan ketentuan dan peraturan yang berlaku.

Sejalan dengan hal tersebut diatas sebagaimana hasil penelitian dari Nuswandari, (2009), Pranata, (2007), Karina, (2018) yang menemukan hasil bahwa kinerja keuangan perusahaan dipengaruhi oleh penerapan GCG secara positif dan signifikan. Artinya semakin baik penerapan GCG yang dilakukan oleh perusahaan maka akan dapat meningkatkan kinerja perusahaan tersebut. Dari keterangan tersebut maka dapat disimpulkan sementara bahwa Good Corporate Governance berpengaruh secara positif dan signifikan terhadap kinerja keuangan Bank Umum Syariah yang diukur dengan Return On Assets (ROA).

\section{METODE PENELITIAN}

\section{Jenis penelitian}

Dari segi pendekatan, maka penelitian ini jenisnya adalah penelitian kuantitatif. Sedangkan dari segi tingkat penjelasannya, maka penelitian ini berjenis asosiatif yaitu penelitian yang bertujuan melihat pengaruh variabel independen (GCG) terhadap variabel dependen (kinerja keuangan BUS).

Penelitian ini dilakukan pada laporan kinerja keuangan Bank Umum Syariah periode 2012-2018 yang dipublikasikan melalui Web. www.bi.go.id dan www.ojk.go.id. Dalam menentukan sampel dilakukan dengan teknik purposive sampling. Jumlah BUS yang mempublikasikan laporan kinerja keuangan adalah 14 BUS selama dari periode 2012-2018.

\section{Pengukuran Variabel}

Penelitian menggunakan dua variabel yaitu Good Corporate Governance (GCG) sebagai variabel independen dan kinerja keuangan sebagai variabel dependen. Pengukuran dari kedua variabel adalah:

1. Good Corporate Governance (GCG), yaitu penerapan tata kelola yang dilakukan oleh Bank Umum Syariah guna meningkatkan kinerjanya dengan berpedoman pada prinsip keterbukaan, akuntabilitas, responsibility, independensi dan kewajaran. Pengukuran GCG 
didasarkan pada penerapan yang dilakukan oleh BUS berdasarkan peraturan Bank Indonesia yang terdiri dari 11 point yaitu : (1) pelaksanaan tugas dan tanggung jawab dewan komisaris, (2) pelaksanaa tugas dan tanggung jawab direksi, (3) kelengkapan dan pelaksanaan tugas komite, (4) penanganan benturan kepentingan, (5) penerapan fungsi kepatuhan bank, (6) penerapan fungsi audit, (7) penerapan fungsi ekstern, (8) penerapan fungsi manjemen risiko dan pengendalian intern, (9) penyediaan dana kepada pihak terkait dan debitu besar, (10) transparansi kondisi keuangan dan non bank, laporan pelaksanaan gcg dan laporan internal, (11) rencana strategi bank. Berdasarkan penerapan 11 point tersebut, maka penilaian GCG dilakukan dengan cara:

\section{$\mathrm{GCG}=$ bobot self assesment $\times$ peringkat yang diperoleh}

2. Kinerja Keuangan, yaitu gambaran yang menunjukkan prestasi dari Bank Umum Syariah dalam mengelola dan mengendalikan asset dalam memperoleh laba. Pengukuran kinerja dilakukan dengan menggunakan Return on Assets (ROA) dengan menggunakan rumus :

$$
\mathrm{ROA}=\frac{\text { laba setelah pajak }}{\text { total aset }} \times 100 \%
$$

\section{Metode Analisis Data}

Mendeskripsikan dan menjelaskan karakteristik variabel-variabel penelitian dengan analisis deskriptif dengan menyajikan angka mean, median, standar deviasi. Dalam mengolah data penelitian ini dilakukan dengan bantuan aplikasi Eviews. Adapun persamaan regresi penelitian ini adalah

$$
\mathrm{KK}=\mathrm{a}+\mathrm{b}_{1} \mathrm{GCG}+\mathrm{e}
$$

Dimana :

$$
\begin{array}{ll}
\mathrm{KK} & =\text { Kinerja Keuangan } \\
\mathrm{a} & =\text { konstanta } \\
\mathrm{b} & =\text { koefisien regresi } \\
\text { GCG } & =\text { Good Corporate Governance }
\end{array}
$$

\section{HASIL DAN PEMBAHASAN}

\section{Gambaran Data Penelitian}

Data penelitian dilakukan dengan melalui studi dokumentasi yaitu annual report pada masing-masing BUS dari periode 2012-2018. Berikut ini data tentang ROA dan penerapan GCG dari BUS adalah : 
Tabel 2. ROA Pada BUS Periode 2012-2013

\begin{tabular}{lccccccc}
\hline \multirow{2}{*}{ Bank Umum Syariah } & \multicolumn{7}{c}{ Tahun } \\
\cline { 2 - 8 } & 2012 & 2013 & 2014 & 2015 & 2016 & 2017 & 2018 \\
\hline Bank Syariah Mandiri & $2,25 \%$ & $1,54 \%$ & $0,18 \%$ & $0,56 \%$ & $0,59 \%$ & $0,59 \%$ & $0,08 \%$ \\
Bank Rakyat Indonesia Syariah & $1,19 \%$ & $1,15 \%$ & $0,08 \%$ & $0,77 \%$ & $0,95 \%$ & $0,51 \%$ & $0,43 \%$ \\
Bank Victoria Syariah & $1,43 \%$ & $0,50 \%$ & $1,87 \%$ & $-2,39 \%$ & $-2,19 \%$ & $0,36 \%$ & $0,32 \%$ \\
Bank Bukopin Syariah & $0,55 \%$ & $0,69 \%$ & $0,27 \%$ & $0,79 \%$ & $1,12 \%$ & $0,02 \%$ & $0,02 \%$ \\
Bank BCA Syariah & $0,80 \%$ & $1 \%$ & $0,80 \%$ & $1 \%$ & $1,10 \%$ & $1,20 \%$ & $1,20 \%$ \\
Bank Aceh Syariah & $3,66 \%$ & $3,44 \%$ & $2,13 \%$ & $2,83 \%$ & $2,48 \%$ & $2,51 \%$ & $2,38 \%$ \\
Bank Mega Syariah & $3,81 \%$ & $2,33 \%$ & $0,29 \%$ & $0,30 \%$ & $2,63 \%$ & $1,56 \%$ & $0,93 \%$ \\
Bank Jabar Banten Syariah & $0,68 \%$ & $0,91 \%$ & $0,69 \%$ & $0,25 \%$ & $-8,09 \%$ & $-5,69 \%$ & $0,54 \%$ \\
\hline Sun
\end{tabular}

Sumber: Data diolah untuk penelitian ini

Tabel 3. Penerapan GCG pada BUS 2012-2018

\begin{tabular}{lccccccc}
\hline \multirow{2}{*}{ Bank Umum Syariah } & \multicolumn{7}{c}{ Tahun } \\
\cline { 2 - 8 } & 2012 & 2013 & 2014 & 2015 & 2016 & 2017 & 2018 \\
\hline Bank Syariah Mandiri & 2,25 & 1,85 & 2,12 & 2 & 1 & 1,35 & 1 \\
Bank Rakyat Indonesia Syariah & 1,38 & 1,35 & 1,74 & 1,61 & 1,6 & 1,57 & 1,54 \\
Bank Victoria Syariah & 2,07 & 1,66 & 1,93 & 3 & 1,97 & 1,62 & 1,56 \\
Bank Bukopin Syariah & 1,5 & 1,5 & 2 & 1,5 & 1,5 & 1,5 & 1,5 \\
Bank BCA Syariah & 1,8 & 1,55 & 1 & 1 & 1 & 1 & 1 \\
Bank Aceh Syariah & 2,3 & 2,17 & 1,9 & 1,95 & 1,64 & 2,95 & 2,83 \\
Bank Mega Syariah & 1,8 & 1,869 & 2 & 1,54 & 1,65 & 1,37 & 1,2 \\
Bank Jabar Banten Syariah & 2,53 & 1,78 & 1,89 & 2,5 & 2,54 & 2,54 & 2,51 \\
\hline
\end{tabular}

Sumber: Data diolah untuk penelitian ini

\section{Analisis Statistic Descriptive}

Berikut ini hasil statistic desdirptif yang dilakukan melalui bantuan aplikasi eviews:

Tabel 4 Uji Statistic Descriptive

\begin{tabular}{lcc}
\hline & ROA & GCG \\
\hline Mean & 0.672500 & 1.768554 \\
Maximum & 3.810000 & 3.000000 \\
Minimum & -8.090000 & 1.000000 \\
Std. Dev. & 1.925379 & 0.502247 \\
\hline
\end{tabular}

Sumber: Hasil Pengolahan Eviews

Tabel diatas menunjukkan bahwa nilai rata-rata ROA sebesar 0.67 , nilai minimum sebesar -8,09, nilai maksimum ROA sebesar 3,81 dan nilai standar deviasi 1.92. sedangkan untuk GCG diperoleh nilai rata-rata 1.76 , nilai minimum sebesar 1, nilai maksimum sebesar sebesar 3 dan nilai standar deviasi sebesar 0.50 . 


\section{Uji Normalitas}

Dalam uji normalitas digunakan uji Jargue-bera, dengan tujuan untuk melihat masingmasing variabel berdistribusi normal atau tidak.

\section{Gambar 1. Uji Normalitas}

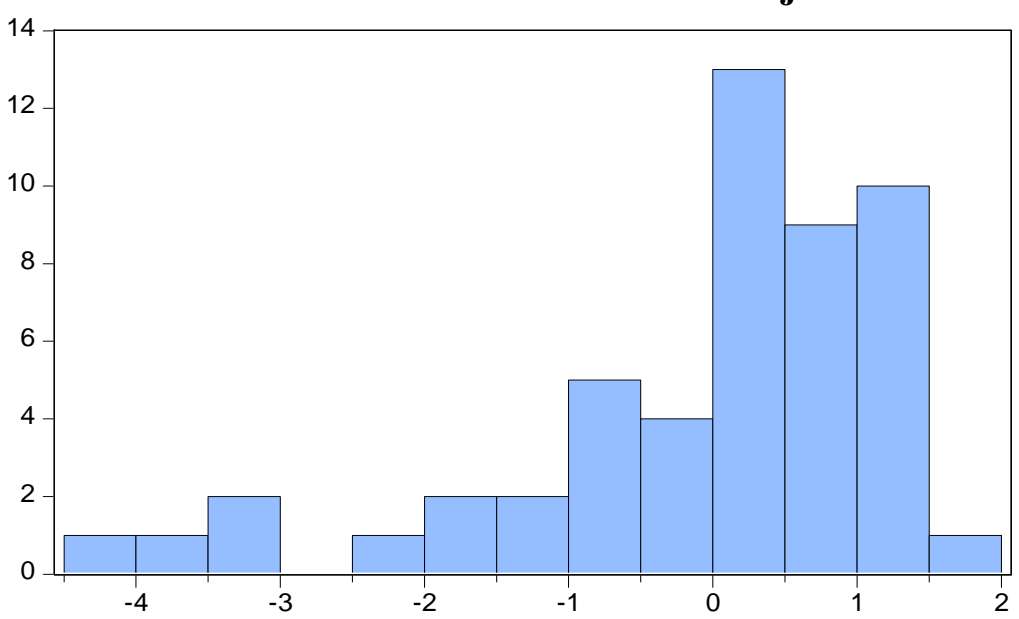

\begin{tabular}{|lc|}
\hline Series: Standardized Residuals \\
Sample 2012 2018 \\
Observations & 51 \\
Mean & $-7.84 \mathrm{e}-17$ \\
Median & 0.328480 \\
Maximum & 1.866698 \\
Minimum & -4.039178 \\
Std. Dev. & 1.356570 \\
Skewness & -1.397613 \\
Kurtosis & 4.570908 \\
& \\
Jarque-Bera & 21.84722 \\
Probability & 0.000018 \\
\hline
\end{tabular}

Nilai Jargue-bera diperoleh 21,84, nilai chi square dengan tingkat signifikansi sebesar $5 \%$ diperoleh 74.46. Dari hasil tersebut dapat dilihat bahwa nilai Jargue-bera yaitu 21.84 lebih kecil dari nilai chi square sebesar 74.46, kondisi ini menandakan bahwa data penelitian ini berdistribusi normal.

\section{Analisis Regresi}

Berikut ini hasil uji regresi sederhana, yaitu:

Tabel 5. Uji Regresi Sederhana

Dependent Variable: ROA

Method: Panel Least Squares

Date: 03/5/21 Time: 20:37

Sample: 20122018

Periods included: 7

Cross-sections included: 8

Total panel (balanced) observations: 56

\begin{tabular}{|c|c|c|c|c|}
\hline Variable & Coefficient & Std. Error & $\mathrm{t}$-Statistic & Prob. \\
\hline C & 2.004715 & 0.939737 & 2.134554 & 0.0267 \\
\hline GCG & 0.523660 & 0.511488 & -1.474053 & 0.1121 \\
\hline
\end{tabular}

Sumber: Hasil Pengolahan Eviews

Dari tabel diatas dapat disusun persamaan regresi sederhana dalam penelitian ini:

$$
\mathrm{KK}=2.004715+0.523660 \mathrm{GCG}+\mathrm{e}
$$

Persamaan regresi sederhana tersebut dapat diinterpretasikan sebagai berikut:

a) Nilai konstanta sebesar 2.004715, artinya apabila nilai GCG nilainya pada posisi 0 maka nilai ROA sebesar 2.004715

b) Nilai koefisien dari GCG sebesar 0.523660, artinya apabila GCG penerapannya mengalami peningkatan sebesar 1 satuan, maka nilai koefisien ROA akan mengalami 
kenaikan sebesar 0.523660 persen dengan asumsi bahwa semua variabel yang lainnya tetap.

\section{Uji Hipotesis}

Berdasarkan tabel 5 diatas dapat dilihat bahwa nilai probabilitasnya adalah 0.1121. Jika nilai ini dibandingkan dengan tingkat signifikasi yang ditentukan yaitu $5 \%(0.05)$, maka nilai prob. 0.1121 lebih besar dari nilai sig. sebesar 0.05. Artinya bahwa penerapan GCG tidak berpengaruh terhadap kinerja keuangan pada BUS periode 2012-2018.

\section{Koefisien Determinasi}

Tabel 6. Uji Koefisien Determinasi

Dependent Variable: ROA
Method: Panel Least Squares
Date: 03/5/21 Time: 20:40
Sample: 2012 2018
Periods included: 7
Cross-sections included: 8
Total panel (balanced) observations: 56
R-squared $\quad 0.083618$ Mean dependent var

Sumber: Hasil Pengolahan Eviews

Nilai R-Square menunjukkan sebesar 0.08361, artinya bahwa penerapan Good Corporate Governance mempengaruhi Return on Assets pada Bank Umum Syariah sebesar 8.36 persen sisanya sebesar 91.64 persen dipengaruhi oleh variabel-variabel lain yang tidak dibahas dalam penelitian ini, dalam arti bahwa masih banyak variabel independen lainnya yang dapat mempengaruhi kinerja keuangan perusahaan yang diukur dengan ROA.

\section{Pembahasan}

Dari hasil penelitian yang dilakukan berdasarkan analisis data dengan bantuan aplikasi eviews dapat dihasilkan bahwa penerapan GCG tidak berpengaruh terhadap kinerja keuangan pada Bank Umum Syariah. Hasil ini bertentangan dengan teori yang menyatakan bahwa semakin baik penerapan GCG maka semakin meningkat kinerja keuangan perusahaan. Hasil ini bertentangan dengan penelitian (Putri, 2006) (Darmawati, 2005) (David, 2011) dan sejalan dengan penelitian (Paradita, 2007).

Tidak berpengaruhnya penerapan GCG terhadap kinerja keuangan pada Bank Umum Syariah disebabkan karena pada umumnya perusahaan perbankan dalam aktivitas operasionalnya sudah menerapkan disiplin yang tinggi. Semua aktivitas yang akan dilaksanakan didasarkan pada standar operasional prosedur secara efektif. Artinya penerapan good corporate governance tersebut sudah terbiasa dilaksanakan pada setiap aktivitasnya.

Pada umumnya perusahaan perbankan mempunyai aturan dan regulasi yang lebih ketat dari perusahaan bidang lainnya. Dalam penerapan aktivitas operasionalnya perusahaan perbankan senantiasa berlandaskan pada prinsip transparansi, akuntabilitas, pertanggungjawaban, independensi dan kewajaran. Bank Indonesia sebagai induk dari perusahaan perbankan juga melakukan control yang efektf dalam penerapan GCG tersebut pada perusahaan perbankan pada umumnya dan Bank Umum Syariah pada khususnya. Pada 
kondisi inilah yang menyebabkan penerapan GCG tidak dapat dijadikan sebagai faktor yang mempengaruhi kinerja keuangan pada Bank Umum Syariah

\section{SIMPULAN, KETERBATASAN DAN SARAN}

Berdasarkan hasil pengujian dan analisis data penelitian ini dapat disimpulkan bahwa Good Corporate Governance tidak berpengaruh terhadap kinerja keuangan pada Bank Umum Syariah Periode 2012-2018. Penelitian ini hanya menggunakan satu variabel dependen, Untuk penelitian kedepannya perlu untuk mempertimbangkan variabel-variabel lain atau tetap menggunakan GCG namun dengan menggunakan indikator-indikator semisal komite audit independen, ukuran bank dan indicator lain dari kinerja keuangan seperti ROE, ROI.

\section{DAFTAR PUSTAKA}

Agrum, P. (n.d.). Pengaruh Kualitas Penerapan GCG Terhadap Kinerja Keuangan Pada Bank Umum Syariah. Jurnal Ekonomi dan Bisnis Islam, 2(1).

Ardhi Abdillah, d. (2015, Agustus). Pengaruh GCG terhadap Kinerja Keuangan pada Perusahaan Pemenang Annual Report Award Periode 2010-2012. Jurnal Administrasi Bisnis (JAB, 25(2).

Bank, I. (2010). Surat Edaran tentang Pelaksanaan GCG bagi BUS dan UUS. Jakarta.

Brigham, E., \& Houston, J. (2006). Fundamentals of Financial Management (Dasar-Dasar Manajemen Keuangan). Jakarta: Salemba Empat.

Darmawati, D. d. (2005). Hubungan Corporate Governance, Kinerja Perusahaan dan Reaksi Pasar. Jurnal Riset Akuntansi Indonesia, 8(1), 65-81.

David, T. R. (2011, May ). Pengaruh GCR terhadap Profitabilitas dan Kinerja Perusahaan Perbankan. Journal of Business dan Banking, 1(1).

Fahmi, I. (2011). Analisis Kinerja Keuangan. Bandung: Alfabeta.

Hastuti, T. D. (2005). Hubungan antara GCG dan Sturktur Kepemilikan dengan Kinerja Keuangan Perusahaan yang Listing di BEJ. SNA VIII. IAI.

Jumingan. (2011). Analisis Lapora Keuangan. Jakarta: PT. Bumi Aksara.

Kaihatu, T. S. (2006). Good Corporate dan Penerapannya di Indonesia. Jurnal Manajemen dan Kewirausahaan, 8(1), 1-9.

Karina, H. (2018). Pengaruh GCG Terhadap Kinerja Keuangan pada BUS Tahun 2013-2015. Skripsi IAIN Surakarta.

Muh. Arief, E. (2009). The Power of Corporate Governance Teori dan Implementasi. Jakarta: Salemba Empat.

Nur'ainy, R. N. (2013). Implementation of GCG and Its Impact on Corporate Performance: The Mediation Role of Firm Size. Global Business and Management Research: An International Journal, 5(2), 91-104.

Nuswandari, C. (2009). Pengaruh Corporate Governance Perception Indeks Terhadap Kinerja Perusahaan. Jurnal Bisnis dan Ekonomi, 16(2), 70-84.

OECD. (2004). The OECD Principles of Corporate Governance. France: Organization for Economic Co-Operation and Development (OECD) Publications Service. 
Oktapiyani, D. (2009). Pengaruh Penerapan Corporate Governance Terhadap Likuiditas Perbankan Nasional. Skripsi Fakultas Ekonomi Undip.

Paradita. (2007). Pengaruh Penerapan GCG terhadap kinerja keuangan perusahaan yang Termasuk 10 Besar Menurut CGPI. Skripsi USU.

Pranata, y. (2007). Pengaruh Penerapan GCG Terhadap Kinerja Keuangan Perusahaan. Skripsi, Universitas Diponegoro.

Prasinta, D. (2012). Pengaruh GCG Terhadap Kinerja Keuangan. Accounting Analysis Journal, 2(1), 4-17.

Prasojo. (2015, Maret). Pengaruh GCG terhadap Kinerja Keuangan Bank Syariah. Jurnal Dinamika Akuntansi dan Bisnis, 2(1).

Putri, W. (2006). Analisis Pengaruh Corporate Governance dan Jumlah Komisaris Terhadap Kinerja Perusahaan. Prodi Akuntansi UII.

Scott, W. (2003). Financial Accounting Theory. USA: Prentice Hall. 